\title{
MENINGKATKAN PENDAPATAN SUPIR TAKSI PELABUHAN INTERNASIONAL BATAM CENTRE MELALUI KETERAMPILAN BERBAHASA INGGRIS
}

\section{A RISE IN EARNINGS OF BATAM CENTRE INTERNATIONAL PORT TAXI DRIVERS THROUGH ENGLISH SPEAKING SKILL}

\author{
${ }^{1)}$ Ambalegin, ${ }^{2}$ Suhardianto \\ ${ }^{1,2)}$ Program Studi Sastra Inggris \\ Fakultas Ilmu Sosial dan Humaniora, Universitas Putera Batam \\ Jl. Letjen R Soeprapto Muka Kuning Tembesi Batam \\ Email: abhi140475@gmail.com
}

\begin{abstract}
ABSTRAK
Pulau Batam berada pada wilayah strategis antara Singapura dan Malaysia, sehingga menjadi keuntungan bagi pulau ini karena banyak wisatawan asing berkunjung. Untuk itu infrastruktur haruslah mendukung kepariwisataan di Pulau Batam. Bandara dan pelabuhan adalah gerbang bagi wisatawan asing berkunjung ke Pulau Batam. Wisatawan asing yang datang ke Pulau Batam melalui Pelabuhan Internasional Batam Centre akan disambut taksi menuju ke destinasi selanjutnya. Supir taksi sebagai agen wisata harus mampu mengenalkan kearifan lokal Melayu dan menunjukkan tempat-tempat wisata di Pulau Batam. Bahasa Inggris adalah alat komunikasi yang dapat memfasilitasi interaksi antara supir taksi dengan wisatawan asing. Tetapi hampir $80 \%$ supir taksi tidak mampu berbahasa Inggris. Kegiatanini bertujuan untuk melatih kemampuan berbahasa Inggris supir taksi melalui metode pendidikan masyakarat dan pelatihan dengan menggunakan teknik ceramah, diskusi, dan demonstrasi. Hasil dari pengabdian ini adalah meningkatnya kemampuan berkomunikasi bahasa Inggris (18,42\%) supir taksi Pelabuhan International Batam Centre. Kesimpulan dari kegiatan ini adalah keterampilan berkomunikasi Bahasa Inggris sangat penting bagi supir taksi untuk menyambut wisatawan asing yang berkunjung ke Pulau Batam, sehingga mendukung pemerintah Kota Batam menggalakkan usaha kepariwisataan.
\end{abstract}

Kata kunci: Keterampilan Berbahasa Inggris; Peningkatan Pendapatan; Supir Taksi

\begin{abstract}
Batam Island is located in a strategic area between Singapore and Malaysia, so it is an advantage for this island because many foreign tourists visit. Therefore infrastructure must support tourism on Batam Island. The airport and harbor are the gateways for foreign tourists visiting Batam Island. Foreign tourists who come to Batam Island via Batam Center International Port will be welcomed by taxi to their next destination. Taxi drivers as travel agents must be able to introduce Malay local wisdom and show tourist attractions on Batam Island. English is a communication tool that can facilitate interaction between taxi drivers and foreign tourists. But almost $80 \%$ of taxi drivers cannot speak English. This activity aims to train the taxi driver's English language skills through methods of community education and training using lecture, discussion, and demonstration techniques. The result of this dedication is the increased ability to communicate in English (18.42\%) Batam International Port taxi driver. This activity concludes that English communication skills are essential for taxi drivers to welcome foreign tourists visiting Batam Island, thus supporting the Batam City government to promote tourism businesses.
\end{abstract}

Keywords: English Language Skills; Increased revenue; Taxi driver

Submitted : 2 Juni 2019 Revision : 25 Oktober 2019 Accepted : 20 Februari 2020 


\section{PENDAHULUAN}

Pulau Batam yang terletak di provinsi Kepulauan Riau adalah sebuah destinasi bagi pelancong luar negeri.Letak strategis Batam yang dekat dengan Singapura dan Malaysia menjadi keuntungan tersendiri bagi pulau ini, dengan banyaknya wisatawan asing yang datang dan berlibur. Letak geografis yang dikelilingi oleh perairan yang jernih dan biru menawarkan keindahan dan kekayaan alam berupa hasil laut sehingga banyak terdapat pantai-pantai yang indah serta restoran-restoran seafood yang disebut juga dengan kelong. Dengan tersedianya 70 hotel, 2 marina, dan 7 lapangan golf menambah lengkapnya fasilitas bagi wisatawan asing yang datang ke Batam. Kepala Badan Pusat Statistik Kepri, Panusunan Siregar mengatakan bahwa Batam berada di urutan satu jumlah kunjungan wisman di bulan Februari 2018 sebesar 154.473 kunjungan (BPS, 2018).

Pemerintah kota Batam (6/12/2016) mendapatkan penghargaan pariwisata kategori indeks pariwisata tertinggi di Indonesia (Suwadha, 2016). Muhammad Rudi selaku walikota Batam di Jakarta (6/12/2016) memaparkan Batam merupakan kota dengan kunjungna wisatawan terbanyak setelah Bali dan Jakarta. Untuk mencapai sasaran pembangunan pariwisata secara tepat harus dapat melibatkan berbagai lapisan masyarakat dalam rangka meningkatkan kualitas kesejahteraan di daerah pariwisata (Nugraha, Purbawasari, Zubair, \& Novianti, 2019). Keberhasilan pariwisata di Batam tidak lepas dari peran serta semua pemangku kepentingan seperti akademisi, pelaku bisnis, komunitas, pemerintah, dan media. Rudi juga mengingatkan bahwa sektor pariwisata yang sehat akanmenggenjot perekonomian daerah maupun nasional serta membuka lapangan pekerjaan bagi warga sekitar (Suwadha, 2016)

Bandar udara dan pelabuhan internasional merupakan pintu gerbang tamutamu asing yang datang ke Batam.Batam memiliki 1 bandar udara internasional dan 4 pelabuhan laut internasional. Wisatawan mancanegara datang ke Batam melalui jalur udara (Bandara Hang Nadim Batam) dan laut (Pelabuhan Internasional Batam Centre, Harbour Bay, Nongsa Pura, dan Sekupang). Wisatawan mancanegara yang datang melalui jalur tersebut setidaknya membutuhkan transportasi seperti taksi untuk ke tempat tujuan.Jasa transportasi merupakan garda terdepan dan sangat penting dalam melancarkan perjalananwisatawan asing di Batam.

Di Pelabuhan Internasional Batam Centre terdapat 110 supir taksi dibawah naungan wadah Batam Centre Point Taxi yang membantu mengantarkan wisatawan asing ke tempat tujuan. Selain dapat mengantarkan penumpang selamat sampai tujuan, supir taksi merupakan agen informasi tentang Batam dan juga menjadi agen pariwisita kota Batam. Supir taksi juga harus mampu menunjukkan kearifan lokal Melayu Batam dan mempromosikan keindahan Pulau Batam kepada tamu-tamu asing. Apabila ini terlaksana dengan baik maka dapat diharapkan Pulau Batam akan semakin terkenal di luar negeri dan pendapatan supir taksi akan bertambah dengan mengantarkan wisatawan asing tidak hanya ke hotel tetapi ke tempat-tempat menarik lainnya. Untuk itu para supir taksi harus mampu berkomunikasi dengan baik menggunakan Bahasa Inggris.

Jumlah wisatawan mancanegara yang berkunjung ke Batam belum mampu mendongkrak pendapatan mereka. Umumnya sopir taksi hanya dapat mengantarkan wisatawan asing dari bandara ke tempat tujuan sesuai dengan permintaan, misalnya hotel, setelah itu sopir kembali dengan taksi kosong menuju pelabuhan untuk antri lagi menunggu giliran membawa penumpang lain. Keadaannya akan berbeda apabila sopir taksi dapat berbahasa Inggris, mereka dapat mengantarkan dari hotel ke tempat lain sehingga memeroleh pendapatan tambahan. Supir taksi juga dapat memperkenalkan Pulau Batam ke wisatawan asing. Disamping berwawasan dan berkemampuan Bahasa Inggris, supir taksi juga harus menunjukkan sikap yang ramah dan sopan sebagai sebuah kearifan lokal Melayu Batam kepada wisatawan mancanegara sehingga pihak hotel dapat memercayai supir taksi dan wisatawan mancanegara akan meminta bantuan supir taksi untuk seterusnya.

Berdasarkan wawancara dan observasi yang dilakukan oleh tim pengabdi, para supir taksi pelabuhan yang umumnya tamatan SMA/SMK sangat mendambakan adanya pelatihan Bahasa Inggris. Para supir taksi menghadapi kendala berbahasa Inggris ketika 
berhadapan dengan wisatawan asing sebagai penumpang taksi.Brown (2007) mengatakan bahwa kemampuan berbicara bahasa asing merupakan keahlian yang utama, dan kemampuan berbicara merupakan integrasidari semua semua faktor (pengucapan, struktur, kosakata) yang menjadikan bahasa asing sebagai latihan yang cukup berat bagi pelajar.Supir taksi tidak mampu berkomunikasi dengan wisatawan asing. Berdasarkan wawancara dengan supir taksi, sekitar $80 \%$ supir taksi tidak bisa berbahasa Inggris.Ada beberapa kendala yang memengaruhi mereka untuk berbahasa Inggris. Kendala orang dewasa tidak mau berbahasa Inggris karenatidak percaya diri, malu, takut salah, dan kurangnya kosakata Bahasa Inggris (Ambalegin, Suhardianto, \& Kaprawi, 2017). Para sopir taksi menambahkan jangankan untuk menjawab, mendengarkan mereka berbicara saja susah untuk dimengerti. Mereka sangat inginbelajar Bahasa Inggris tetapi tidak mengganggu jadwal kerja para sopir taksi.

Kemampuan menguasai Bahasa Inggris adalah salah satu skill yang diharapkan dimiliki oleh setiap orang untuk bersaing dalam dunia usaha. Crystal (2003) mengatakan faktor sosial-budaya memfasilitasi pentingnya Bahasa Inggris yang ditunjukkan pada posisi-posisi penting yaitu politik, bisnis, hiburan, hubungan internasional, media massa, perjalanan internasional, keamanan internasional, pendidikan, dan komunikasi. Kachruahli bahasa dari India mengatakan mengetahui Bahasa Inggris seperti sebuah gerbang menuju bisnis internasional, teknologi, pengetahuan, dan perjalanan (Kachru, Kachru, \& Nelson, 2006). Semangat dalam belajar Bahasa Inggris menjadi inspirasi sekaligus pelecut semangat bagi orang lain untuk terus belajar.

Berdasarkan permasalahan yang dihadapi para supir taksi Pelabuhan Internasional Batam Centre, tim pengabdi memberikan pelatihan Bahasa Inggris khususnya kemampuan berkomunikasi (Speaking English Skill) tahap pertama sebanyak 3 pertemuan. Hal ini dilakukan agar supir taksi dapat berkomunikasi dalam Bahasa Inggris terhadap wisatawan mancanegara dengan baik. Penggunaan Bahasa Inggris yang baik dan benar akan menjadi salah satu senjata untuk menarik perhatian wisatawan berkunjung dan betah untuk tinggal (Ambalegin, Arianto, \&
Azharman, 2019). Keterampilan yang dimiliki oleh supir taksi antara lain time, traffic, traveling, money, shopping, vacation weather, and work, sementara fungsi-fungsi kebahasaan yang digunakan antara lain; greeting, informing, directing, asking and answering questions, asking for clarification, thanking, apologizing, giving direction, offering, suggesting, and persuading.

Pelatihan tahap kedua dilanjutkan.Tim pengabdi melakukan interview beberapa supir taksi yang telah mengikuti pembinaan sebelumnya. Tim pengabdi menyimpulkan bahwa supir taksi menganggap penting melanjutkan belajar Bahasa Inggris sesuai dengan pengalaman teman supir taksi yang pergi ke Amerika karena kemahirannya berbahasa Inggris. Ini merupakan salah satu motivasi supir taksi untuk belajar Bahasa Inggris di samping menambah pendapatan mereka.Tim pengabdi melaksanakan pengabdian lanjutan dengan materi lanjutan sebanyak 3 pertemuan.

Rustanto menyatakan bahwa pembinan merupakan pemberdayaan untuk meningkatkan kepercayaan, peluang, dan kinerja warga minoritas untuk mencegah dan mengatasi masalah yang ada di lingkungannya (Nugraha et al., 2019). Tim pengabdi memberikan pembinaan berdasarkan kebutuhan peserta melalui pendidikan masyarakat (ceramah) dan pelatihan berbahasa Inggris. Kegiatan pembinaan ini bertujuan memberikan keterampilan berkomunikasi bahasa Inggris supir taksi Pelabuhan Internasional Batam Centre yang dapat memberikan dampak positif pada peningkatan kemampuan berkomunikasi, peningkatan pendapatan peserta, dan target pemerintah dalam meningkatkan industri pariwisata di Pulau Batam.

\section{METODE}

Kegiatan pengabdian tahap 2 menggunakan metode pendidikan masyarakat (ceramah) dan pelatihan. Pelatihan komunikasi berbahasa Inggris dilakukan melalui tiga tahap yang ditunjukkan pada gambar berikut ini. 


\section{Analisis Situasi}

- Melakukan observasi dan wawancara memdiskusikan tentang permasalahan peserta pembinaan

\section{Solusi}

-Pelatihan berbahasa Inggris berbasis kearifan lokal budaya Melayu

\section{Pelatihan}

- Pre-test

-Workshop (ceramah dan demostrasi )

-Post-test

-Praktik lapangan

Gambar 1. Kegiatan pengabdian

Analisis situasi mengawali pengadian ini yang bertujuan mengetahui permasalahan supir taksi dan menentukan metode yang tepat untuk mengatasi permasalah supir taksi, jenis kegiatan pelatihan, materi pelatihan yang sesuai dengan kebutuhan supir taksi, dan waktu dan tempat kegiatan pengabdian.

Target dari pelatihan ini adalah peserta mampu berkomunikasi dalam Bahasa Inggris. Sebelum pelatihan, dilaksanakan latihan tertulis awal (pre-test) dan tanya-jawab lisan berbahasa Inggris untuk mengetahui tingkat kemampuan bahasa Inggris peserta. Workshop tahap 1 diawali dengan ceramah dengan topik greeting, informing, directing, asking and answering questions, dan asking for clarification. Dengan teknik student-center learning, peserta mendemonstrasikan percakapan Bahasa Inggris dengan topik yang telah didiskusikan. Untuk pelatihan tahap kedua, topik yang didiskusikan adalah thanking, apologizing, giving direction, offering, suggesting, dan persuading. Peserta diajak untuk mempraktikkan materi ceramah dengan melakukan latihan percakapan antar teman.Pelatihan ini dilaksanakan selama 2 jam dalam sekali pelatihan.

Masih dalam kegiatan pelatihan,2 supir taksi dipilih acak untuk praktik langsung dengan penumpang di dalam taksi dengan topik sesuai yang didiskusikan. Pada akhir pelatihan, peserta diberi latihan tertulis akhir (post-test) serta diminta untuk menuliskan kekurangan kegiatan pengabdian ini sebagai refleksi tim pengabdi untuk memperbaiki kegiatan pengabdian selanjutnya. Akhir dari pengabdian ini adalah pembagian materi agar supir taksi dapat melanjutkan pelajaran secara mandiri dan jika supir taksi mengalami kendala, mereka dapat menghubungi tim pengabdi.

\section{HASIL DAN PEMBAHASAN}

Mitra sasaran dalam pelaksanaan pengabdian ini adalah supir taksi Serikat Tolong Menolong (STM) Batam Centre Point (BCP) Taksi yang berada di Batam. Supir taksi dalam wadah BCP Taksi terdiri dari 110 supir taksi. Yang mengikuti pelatihan berjumlah 21 supir taksi yang aktif dan selebihnya tidak begitu intens karena bekerja.

Sebelum dilakukan pelatihan, tim pengabdi memberikan latihan tertulis bahasa Inggris dasar untuk mengukur kemampuan peserta karena tes adalah sebuah prosedur sistematis untuk mengobservasi tingkah laku seseorang dan mendeskripsikannya dalam bentuk skala angka atau sistem kategori (Yusuf dalam Mustafidah \& Harjono, 2019). Pelaksanaan kegiatan pengabdian diawali dengan latihan tertulis (pre-test). Hasil pre-test menunjukkan rata-rata nilai pre-testadalah 46 dan hasil dari wawancara berbahasa Inggris dikategorikan rendah. Sesuai hasil awal latihan lisan dan tulisan maka dilaksanakan pelatihan atau workshop dengan teknik ceramah dan demonstrasi. Materi ceramah berhubungan dengan topik percakapan antara supir taksi dan penumpang yaitu greeting, informing, directing, asking and answering questions, asking for clarification, greeting, informing, directing, asking and answering questions, dan asking for clarification. Setelah dilaksanakan pelatihan berbentuk ceramah, selanjutnya dilaksanakan latihan tertulis (post-test). Ratarata nilai post-testadalah 63 dengan rata-rata kenaikan adalah 18,42.

Lebih lengkapnya dapat dilihat dalam tabel 1 berikut ini : 
Tabel 1. Hasil pre-test dan post-test mitra pengabdian

\begin{tabular}{|c|c|c|c|c|c|c|c|c|c|}
\hline \multirow[t]{2}{*}{ Peserta } & \multirow[t]{2}{*}{ Umur } & \multirow{2}{*}{$\begin{array}{l}\text { Pre-test } \\
(0-100)\end{array}$} & \multirow{2}{*}{$\begin{array}{c}\text { Post-test } \\
(0-100)\end{array}$} & \multirow{2}{*}{$\begin{array}{l}\text { Kenaik } \\
\text { an }(\%)\end{array}$} & $\mathrm{Al}$ & 47 & 65 & 75 & 10 \\
\hline & & & & & Kamal & 36 & 70 & 80 & 10 \\
\hline Idul Bahri & 59 & 20 & 40 & 20 & Rony & 27 & 80 & 90 & 10 \\
\hline Dendi & 39 & 60 & 75 & 15 & Jack & 41 & 40 & 65 & 25 \\
\hline Febrizar & 51 & 40 & 60 & 20 & Joni & 46 & 35 & 50 & 15 \\
\hline Afrizal & 45 & 65 & 70 & 5 & Napitupulu & 50 & 20 & 50 & 30 \\
\hline Olly & 22 & 30 & 65 & 35 & Mhd Zen & 47 & 75 & 85 & 10 \\
\hline Syamsul & 41 & 40 & 60 & 20 & Af & 52 & 20 & 40 & 20 \\
\hline Safrizal & 40 & 55 & 70 & 15 & Oli & 19 & 65 & 70 & 5 \\
\hline Uli & 35 & 25 & 50 & 25 & Dendi & 39 & 80 & Sakit (80) & 0 \\
\hline Marwan & 54 & 20 & 50 & 30 & Mes & 36 & 60 & 60 & 0 \\
\hline Erwin & 49 & 0 & 30 & 30 & Rata-rata & & & & 18,42 \\
\hline
\end{tabular}

Hasil tersebut digambarkan sebagai berikut:

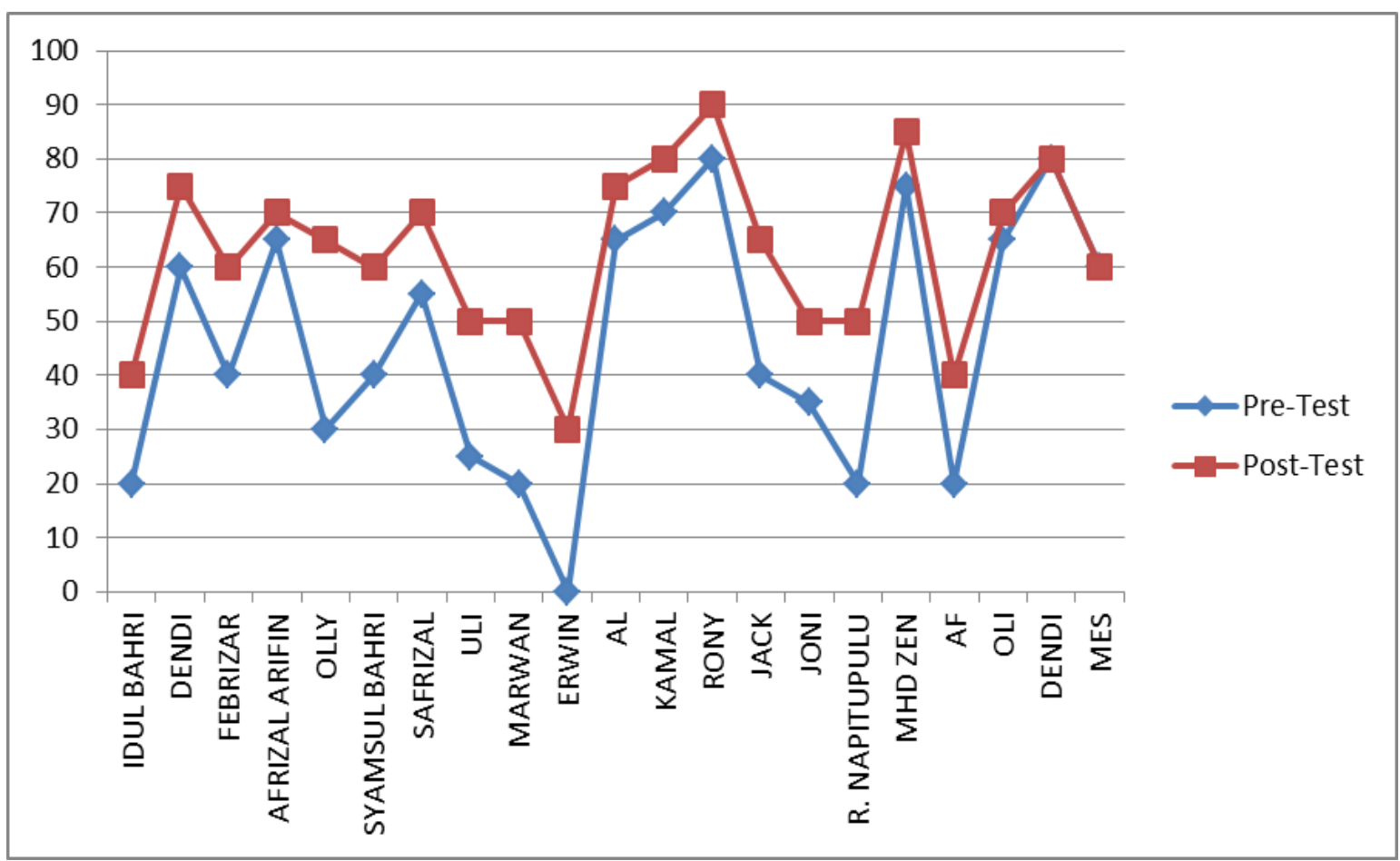

Gambar 2. Diagram kenaikan nilai pre-test dan post-test mitra pengabdian

Kesalahan soal rata-rata adalah pada pembuatan pertanyaan dan membuat respon terhadap pertanyaan dari pelanggan. Serta dari hasil tanya-jawab lisan dalam Bahasa Inggris diketahui rata-rata supir taksi tidak mampu mengucapkan Bahasa Inggris dengan benar, kurangnya kosa kata Bahasa Inggris, dan struktur pembentukan kalimat yang masih kurang (salah). Hal ini wajar karena supir taksi lebih banyak berkomunikasi dengan Bahasa Indonesia. Dari kesimpulan sederhana yang diperoleh maka tim pengabdi meredisain materi 
yang diberikan dalam pelatihan yang dilakukan dua tahap yaitu tanggal 19 dan 26 Maret, dan 2 April 2017 untuk tahap 1 dan 28, 29, dan 30 Agustus 2017 untuk tahap 2 dengan menambahkan pelatihan singkat English Pronunciation dan Grammar.

Pelatihan yang menekankan pada kemampuan berkomunikasi dalam Bahasa Inggris memberikan pengetahuan tentang teknik berkomunikasi berprofesi sebagai supir taksi. Pelatihan ini dibantu oleh beberapa mahasiswa program studiSastra Inggris. Dengan bantuan mahasiswa, peserta dapat dilayani dengan cepat dan mudah tanpa rasa segan. Pelatihan yang dilakukan benar-benar dengan fasilitas apa adanya. Pelatihan dilaksanakan di basecamp di Pelabuhan Internasional Batam Centre tempat para supir taksi menunggu panggilan. Peralatan pelatihan seadanya seperti kertas karton dan alat tulis seadanya. Untuk menambah semangat belajar peserta, tim pengabdi memberikan kudapan berupa gorengan. Ada beberapa peserta yang mengikuti pelatihan dengan tidak selesai ataupun hadir dipertengahan karena peserta sambil bekerja tetapi hal ini bukan merupakan kendala bagi tim pengabdi.

Seperti biasa para supir taksi bermain catur ketika menunggu penumpang tetapi ketika pelatihan dilaksanakan, mereka datang dan duduk di tempat yang disediakan.Supir taksi diberikan materi pembelajaran dengan membagikan kertas materi. Kertas materi berisi contoh dialog dan kosakata Bahasa Inggris berhubungan dengan pekerjaan sebagai supir taksi. Mereka diajarkan mengucapkan kata Bahasa Inggris dengan benar dan membuat kalimat dengan struktur yang benar

Semangat peserta adalah motivasi tim pengabdi untuk melakukan pelatihan. Dengan sabar tim pengabdi melatih mengucapkan (pronunciation) seperti luggage, fare, charge, change, destination, view, trunk, get in, sitbelt, shelter, pedestrian dan lainnya. Banyak dari peserta yang sulit mengucapkan kata-kata tersebut. Selanjutnya peserta diajak membaca dialog dari kertas materi yang diberikan. Lain halnya dengan pembelajaran struktur (grammar), umumnya banyak peserta yang merasa kesulitan dalam membuat kalimat sesuai dengan waktu tertentu.Tetapi peserta harus mengetahui pembentukan kalimat berstruktur. Peserta diberikan pelatihan yaitu penggunaan verb be, is, am, are. Penggunaan verb be untuk mendeskripsikan benda, menunjukkan benda dan waktu. Peserta juga diberikan materi dalam bentuk positif, negatif, dan tanya. Peserta diminta untuk membuat contoh kalimat dengan verb be, is, am, are, dalam bentuk bentuk postif, negatif, dan tanya sesuai dengan pekerjaan. Peserta juga diberikan pelatihan yaitu penggunaan do, does, dan did. Penggunaan do, does, dan did untuk mendeskripsikan kalimat tanya. Peserta juga diberikan materi kalimat tanya5-Wh dan 1-H. Peserta diminta untuk membuat contoh kalimat tanya dengan $5 \mathrm{~W}$ dan $1 \mathrm{H}$.

Di pelatihan kedua pembelajaran Bahasa Inggris dibagi pada tahap perkenalan kosakata seputar salam, percakapan antara supir taksi dan penumpang (vocabulary), pengucapan (pronunciation), struktur (grammar), dan membuat kalimat sederhana.Contoh kata yang sering diucapkan adalahapologize, ashame, sorry, refuse, quite, danlainnya. Di samping itu, tim pengabdi menyisipkan ceramah menjunjung tinggi kesopanan dan keramahtamahan berbasis kearifan lokal Melayu di Batam. Pembelajaran dilanjutkan kepada percakapan yang lebih kompleks seperti expression of thanking, apologizing, persuading, dan lainnya serta pengucapan (pronunciation), struktur (grammar), dan tentunya membuat kalimat sederhana.

Di tahap pertama dan kedua pelatihan, konsep student-center learning ditekankan yaitu dengan mengajak peserta berlatih berbahasa Inggris dengan teman (in-paired practice) yang bertujuan melatih rasa percaya diri mereka untuk berbahasa Inggris. Intidarikomunikasi adalah informasi yang digunakan untuk mengembangkan hubungan antar pertemanan dan membangun kepercayaan antar individu dengan pertemanan seseorang dalam organisasi (Nugraha et al., 2019). Walaupun ada yang tidak serius tetapi mereka cukup senang pada saat pelatihan. Suasana pelatihan cukup menyenangkan walaupun dengan keadaan seadanya. Hal ini dikarenakan peserta menyadari pentingnya pelatihan ini sebagai sebuah pengalaman yang berharga.

Sesuai dengan target pelatihan yaitu mampu berbahasa Inggris, hasil dari pelatihan ini, dapat dilihat dari simulasi percakapan supir taksi dan pengguna taksi dalam bahasa Inggris. Dua peserta dipilih saat simulasi. Percakapan 
berupa pertanyaan tentang jarak dan destinasi yang dapat dikunjungi di Batam.Peserta mulai mampu mendeskripsikan arah tempat menarik di Batam yang dapat dikunjungi wisatawan asing setelah ditenangkan dan diberikan motivasi.Peserta simulasi kedua dapat merespon dengan cukup baik walaupun masih belum begitu lancar tapi masih dapat dikatakan baik untuk peserta jika di bandingkan dengan simulasi awal sebelum pelatihan.

Sebelum pelaksanaan pelatihan, tim pengabdimelakukan simulasi dengan salah satu supir taksi secara acak.Supirtaksi merasa canggung dan gugup berbahasa Inggris karena belum terbiasa dan belum merasa percaya diri.Supir taksi hanya berbiacara seperlunya saja dengan kalimat-kalimat pendek. Di sisi lain, tim pengabdi menyimpulkan ternyata siapa saja dapat mengalami rasa canggung dan gugup ketika tidak memiliki cukup pengetahuan untuk diutarakan. Dengan manfaat yang dapat diperoleh setelah pelatihan, akhirnyapelatihan dilanjutkan dengan pemberian materi fotokopi bahasa Inggris.Hal ini diharapkan agar supir taksi dapat belajar mandiri dan memiliki kemampuan berbahasa Inggris secara aktif ketika melayani tamu asing.

Keterampilan yang sudah dimiliki peserta dan kemampuan kerja sama akan sangat efektif dalam memberikan informasi dan mendukung program pemerintah (Siregar, Anwar, \& Sangaji, 2019). Dengan latar belakang profesi yang sama sebagai supir taksi, komunikasi antar peserta menjadi lebih mudah, mudah bekerja sama, serta mendukung tercapainya tujuan mempunyai keterampilan berkomunikasi yang mendukung profesi sebagai supir taksi dan organisasi Batam Centre Point Taksi, serta program pemerintah Kota Batam.

\section{SIMPULAN}

Supir taksi Pelabuhan Internasional Batam Centre memiliki kemampuan berbahasa Inggris dasar. Mereka harus diberi pembekalan dalam memahami Bahasa Inggris lebih dalam.Komunikasi yang terjadi antara supir taksi dan pengguna jasa supir taksi harus berjalan dengan baik sehingga hubungan supir taksi dan pengguna jasa taksi dapat berjalan dengan lancar.Dampak positif bagi supir taksi yaitu dapat menambah pelanggan dan meningkatkan pendapatan mereka.

Untuk mengerti agar pesan tersampaikan tidaklah mudah.Pengaturan katakata dalam sebuah kalimat pada ujaran (utterance) haruslah tepat dan jelas.Seperti pada kalimat-kalimat dalam Bahasa Inggris, pembentukan kalimat dalam Bahasa Inggris haruslah disesuaikan dengan waktu dimana kegiatan dilakukan. Jika pembentukan kalimat tidak sesuai dengan waktu (tense) maka akan mengakibatkan salah dalam mengartikan kalimat. Pelatihan berbentuk workshop merupakan hal yang cukup efektif dalam mengasah kemampuan supir taksi Pelabuhan Internasional Batam Centre berbahasa Inggris. Pelatihan dengan durasi waktu yang efektif dan intens dapat memecahkan permasalahan supir taksi berbahasa Inggris.

Keberhasilan pelatihan Bahasa Inggris kepada supir taksi dapat menjadi referensi untuk melanjutkan pelatihan Bahasa Inggris di tempat lain. Rencana pelatihan akan dilakukan di kampung tua terhadap organisasi kepemudaan yang diharapkan dapat menunjukkan kearifan lokal budaya Melayu kepada wisatawan lokal, nasional, atau internasional. Skill berkomunikasi sangat penting dalam menjalin hubungan dengan pengunjung dan sebagai alat untuk mempromosikan kearifan lokal dan keindahan alam kampung tua di Batam.

\section{DAFTAR PUSTAKA}

Ambalegin, Arianto, T., \& Azharman, Z. (2019). Kampung Tua Nongsa Sebagai Tujuan Wisata Berbasis Kearifan Lokal Budaya Melayu Batam. Dinamisia : Jurnal Pengabdian Kepada Masyarakat Universitas Lancang Kuning, 3 (Juni), 67-75, https://doi.org/https://doi.org/10.31849 /dinamisia.v3i2.2863

Ambalegin, Suhardianto, \& Kaprawi, N. (2017). Obstacles Facing Learners In Speaking English: Non-English Teacher's Perspective, Putra Batam School. Obstacles Facing Learners In Speaking English: Non-English Teacher's Perspective, Putra Batam School., 25(S), 119-127. 
BPS. (2018). Tahun 2018 jumlah wisatawan di Batam meningkat. Retrieved May 4, 2018, from https://www.batamfm.com/artikel/bare lang/item/222-tahun-2018-jumlahwisatawan-di-batam-meningkat

Brown, H. D. (2007). Teaching By Principles: An Interactive Approach To Langauge Pedagogy (3rd ed.). San Francisco, USA: Pearson Longman.

Crystal, D. (2003). English as a global language (Second Edi). Cambridge, UK: Cambridge University Press.

Kachru, B. B., Kachru, Y., \& Nelson, C. L. (2006). The Handbook Of World Englishes (First Edit). Oxford, UK: Blacwell Publishing Ltd.

Mustafidah, H., \& Harjono. (2019). Implementasi Program QUEST Untuk Menganalisis Butir Soal Bagi guruguru SMP Muhammadiyah 2 Karangwelas. Jurnal Pengabdian Dan Pemberdayaan, 3(2), 321-328. https://doi.org/10.30595/jppm.v3i2.33 78

Nugraha, A. R., Purbawasari, S., Zubair, F., \& Novianti, E. (2019). Pemberdayaan Masyarakat Melalui Pelatihan Komunikasi Efektif Berbasis Potensi Wisata Dan Kearifan Lokal. Jurnal Pengabdian Dan Pemberdayaan Masyarakat,, 3(1), 123-132.

Siregar, J. H., Anwar, C., \& Sangaji, M. (2019). Pelatihan Pengelolaan Aplikasi Sistem Informasi Bagi Warga Kelurahan Sawah Baru, Tangerang Selatan. Jurnal
Pengabdian Dan Pemberdayaan Masyarakat, 3(2), 343-350. https://doi.org/10.30595/jppm.v3i2.41 67

Suwadha, D. (2016). Dapat penghargaan pariwisata, Walikota Rudi targetkan 1,9 juta wisman ke Batam. Retrieved December 6, 2016, from

https://www.wartakepri.co.id/2016/12/ 06/dapat-penghargaan$\%$ E2\%80\%8Epariwisata-walikotarudi-targetkan-19-juta-wisman-kebatam/ 